\title{
ARTICLE \\ Factor XI gene variants in factor XI-deficient patients of Southern Italy: identification of a novel mutation and genotype-phenotype relationship
}

\author{
Giovanni L Tiscia ${ }^{1}$, Giovanni Favuzzi ${ }^{1}$, Maria R Lupone ${ }^{2}$, Filomena Cappucci ${ }^{1}$, Michele Schiavulli ${ }^{2}$, Valentina Mirabelli ${ }^{3}$, \\ Giovanna D'Andrea ${ }^{4}$, Elena Chinni ${ }^{1}$, Nicola Giuliani ${ }^{5}$, Rocco Caliandro ${ }^{3}$ and Elvira Grandone ${ }^{1}$
}

Congenital Factor XI (FXI) deficiency shows a high variability in clinical phenotype. To date, many allele variants have been shown to cause this bleeding disorder. However, the genotype-phenotype relationship is difficult to establish. This report provides insights into this bleeding disorder. Sixteen unrelated Italian index cases with congenital FXI deficiency and their relatives were investigated. After the identification of the deficiency, we obtained DNA from each subject and analyzed the FXI gene using direct sequencing. We identified 5 and 11 individuals with severe and moderate deficiency of FXI activity, respectively. Most patients (8/16) carried mutations in the Apple 2 domain and 4 patients showed c.403G > T (p.Glu135*; type II mutation). Four novel compound heterozygosities were identified. Bleeding symptoms were present in two severely deficient subjects carrying the combinations c.901T > C (p.Phe301Leu)/c.1556G > A (p.Trp519*) and c.943G > A (p.Glu315)/c.1556G > A (p.Trp519*), respectively. Bleeding episodes were also observed in the presence of a moderate deficiency in two individuals heterozygous for $c .449 C>T$ ( $p . T h r 150 M e t)$ and c.1253G > T (p.Gly418Val), respectively. One novel mutation, c.1682C > A (p.Ala561Asp), was identified as potentially deleterious in an asymptomatic individual. We confirm an unclear prediction of phenotype from mutational data. The FXI levels should be coupled with FXI analysis for a more comprehensive prediction of the bleeding phenotype in FXI deficiency.

Human Genome Variation (2017) 4, 17043; doi:10.1038/hgv.2017.43; published online 9 November 2017

\section{INTRODUCTION}

Congenital Factor XI (FXI) deficiency, which is inherited as an autosomal recessive trait, ${ }^{1}$ is a mild bleeding disorder that often goes undiagnosed. ${ }^{2}$ Severe deficiency is defined as FXI $<15-20 \mathrm{lU} / \mathrm{dll}^{3}$ Individuals with levels between $20 \mathrm{lU} / \mathrm{dl}$ and the lower limit of the normal range, generally $65-80 \mathrm{lU} / \mathrm{dl}$, are classified as having partial or mild deficiency. ${ }^{3}$

The gene (F11) of FXI contains 15 exons and 14 introns, and is located on the long arm of chromosome 4 (4q35). ${ }^{4}$ Homozygotes or compound heterozygotes typically show severe FXI deficiency, whereas heterozygotes show partial or mild deficiency. ${ }^{5} \mathrm{FXI}$ deficiency has been predominantly diagnosed in Ashkenazi Jews. ${ }^{6}$ Other clusters of FXI-deficient groups have been observed among Iraqi Jews and Arabs, and among Basques and Caucasians (United Kingdom and France). ${ }^{5}$ In Ashkenazi Jews, the c.403G $>T$ (p.Glu135*; so-called type II mutation) and the c.901 T>C (p.Phe301Leu; type III mutation) genetic variants within the F11 gene are prevalent and strongly associated with FXI deficiency. ${ }^{7}$ These variants were also investigated in an unselected population of 3,879 Italian individuals with an allele frequency of 0.00064 (type II) and 0.00051 (type III), respectively, and in 31 Italian deficient-FXI patients, the type II mutation was more prevalent than the the type III mutation. ${ }^{8}$ In FXI deficiency, bleeding episodes are typically injury related, particularly those involving loci with higher fibrinolytic activity, such as the oral cavity, nose, tonsils, and urinary tract. ${ }^{9,10}$ Menorrhagia is the most frequent spontaneous episode in women with severe deficiency, ${ }^{5}$ whereas postpartum hemorrhage occurs in $\sim 20 \%$ of affected women. ${ }^{11,12}$ Some patients with low levels of FXI may not bleed at all, ${ }^{13}$ whereas other subjects can show a different susceptibility to bleeding in the presence of similar hemostatic challenges. ${ }^{9-11}$ Postoperative bleeding events are common in subjects with severe FXI deficiency, whereas individuals with partial or mild FXI deficiency show a weak tendency for postoperative blood loss. ${ }^{3}$ Thus, a clear understanding of the relationship between the F11 genotype and phenotype of individuals with FXI deficiency is still needed. Herein, we report our findings in subjects of Caucasian ancestry with FXI deficiency to provide additional insights into this bleeding disorder.

\section{MATERIALS AND METHODS}

\section{Subjects}

Individuals with alterations in activated partial thromboplastin time referred to the Atherosclerosis and Thrombosis Unit of IRCCS 'Casa Sollievo della Sofferenza' were described. All subjects examined were from Southern Italy. All patients provided informed written consent for the use of their clinical and bio-molecular data. A detailed collection of present and past clinical history was performed to investigate the presence of any bleeding events. In detail, all the participants were requested to provide details of the conditions potentially causing bleeding, such as surgical procedures, pregnancy, and any injuries, or any spontaneous blood losses. In the case of a referred bleeding episode, medical records were requested

\footnotetext{
${ }^{1}$ IRCCS 'Casa Sollievo della Sofferenza', Unità di Aterosclerosi e Trombosi, San Giovanni Rotondo (Foggia), Italy; ${ }^{2}$ Centro Regionale per le Emocoagulopatie, Azienda Ospedale 'Santobono-Pausillipon', Napoli, Italy; ${ }^{3}$ Istituto di Cristallografia, CNR, Bari, Italy; ${ }^{4}$ Genetica Medica, Università degli Studi di Foggia, Foggia, Italy and ${ }^{5}$ IRCCS 'Casa Sollievo della Sofferenza', Direzione Sanitaria, San Giovanni Rotondo (Foggia), Italy.
}

Correspondence: Elvira Grandone (e.grandone@operapadrepio.it)

Received 7 April 2017; revised 27 July 2017; accepted 2 August 2017 
Table 1. Clinical and molecular findings of the families investigated

\begin{tabular}{|c|c|c|c|c|c|c|c|}
\hline $\begin{array}{l}\text { Family subject, } \\
\text { year of birth }\end{array}$ & $\begin{array}{l}F X I: C \\
(U d L-1)\end{array}$ & Amino acid & $\begin{array}{l}\text { Gene } \\
\text { region }\end{array}$ & Domain & Genotype & Symptoms & Challenges \\
\hline \multicolumn{8}{|l|}{ Family 1} \\
\hline P1, F, 2005 & $<1$ & $\begin{array}{l}\text { p.Ala108Thr } \\
\text { c. } 325+1 G>A\end{array}$ & $\begin{array}{c}\text { Exon } 4 \\
\text { Intron } 4\end{array}$ & $\begin{array}{c}\text { Apple } 2 \\
-\end{array}$ & $\begin{array}{l}\text { Comp } \\
\text { Hetero }\end{array}$ & Asymptomatic & \\
\hline Father, 1980 & 32 & c. $325+1 G>A$ & Intron 4 & - & Hetero & Epistaxis & \\
\hline Mother, 1986 & 35 & p.Ala108Thr & Exon 4 & Apple 2 & Hetero & Asymptomatic & \\
\hline \multicolumn{8}{|l|}{ Family 2} \\
\hline P2, F, 1987 & 38.4 & p.Glu135 a & Exon 5 & Apple 2 & Hetero & Asymptomatic & \\
\hline \multicolumn{8}{|l|}{ Family 3} \\
\hline P3, M, 1937 & 42 & p.Glu135 a & Exon 5 & Apple 2 & Hetero & $\begin{array}{l}\text { Asymptomatic, aidiopathic } \\
\text { superficial vein thrombosis }\end{array}$ & $\begin{array}{l}\text { Knee prosthesis implantation; } \\
\text { multiple tooth extraction; } \\
\text { tonsillectomy; surgery for } \\
\text { inguinal hernia }\end{array}$ \\
\hline \multicolumn{8}{|l|}{ Family 4} \\
\hline P4, F, 1977 & 34.3 & p.Glu135 & Exon 5 & Apple 2 & Hetero & Asymptomatic & $\begin{array}{l}\text { Appendicectomy; gynaecological } \\
\text { laparoscopy }\end{array}$ \\
\hline \multicolumn{8}{|l|}{ Family 5} \\
\hline P5, F, 1959 & $<1$ & $\begin{array}{l}\text { p.Glu135a } \\
\text { p.Cys136Arg }\end{array}$ & $\begin{array}{l}\text { Exon } 5 \\
\text { Exon } 5\end{array}$ & $\begin{array}{l}\text { Apple } 2 \\
\text { Apple } 2\end{array}$ & $\begin{array}{l}\text { Comp } \\
\text { Hetero }\end{array}$ & Asymptomatic & Two pregnancies \\
\hline \multicolumn{8}{|l|}{ Family 6} \\
\hline P6, M, 1990 & 34 & p.Thr150Met & Exon 5 & Apple 2 & Hetero & Epistaxis & \\
\hline Father, 1966 & 52 & p.Thr150Met & Exon 5 & Apple 2 & Hetero & Asymptomatic & \\
\hline Sister, 1978 & 118.5 & No mutation & NA & NA & NA & Asymptomatic & \\
\hline \multicolumn{8}{|l|}{ Family 7} \\
\hline P7, M, 2005 & 37 & p.Thr150Met & Exon 5 & Apple 2 & Hetero & Asymptomatic & Genito-urinary surgery \\
\hline Father, 1974 & 43 & p.Thr150Met & Exon 5 & Apple 2 & Hetero & Asymptomatic & \\
\hline \multicolumn{8}{|l|}{ Family 8} \\
\hline P8, F, 2005 & 45.3 & p.Arg160His & Exon 5 & Apple 2 & Hetero & Asymptomatic & Adeno-tonsillectomy \\
\hline Mother, 1975 & 43.1 & p.Arg160His & Exon 5 & Apple 2 & Hetero & Asymptomatic & \\
\hline Sister, 2005 & 47.3 & p.Arg160His & Exon 5 & Apple 2 & Hetero & Asymptomatic & Adeno-tonsillectomy \\
\hline \multicolumn{8}{|l|}{ Family 9} \\
\hline P9, M, 1992 & 33.6 & p.Cys230Arg & Exon 7 & Apple 3 & Hetero & Asymptomatic & Surgery for sinus pilonidalis \\
\hline Father, 1964 & 84.2 & No Mutation & NA & NA & NA & Asymptomatic & \\
\hline Mother, 1962 & 33.9 & p.Cys230Arg & Exon 7 & Apple 3 & Hetero & Asymptomatic & \\
\hline \multicolumn{8}{|l|}{ Family 10} \\
\hline P10, F, 1998 & 3.8 & $\begin{array}{l}\text { c. } 595+3 A>G \\
\text { p.Phe301Leu }\end{array}$ & $\begin{array}{l}\text { Intron } 6 \\
\text { Exon } 9\end{array}$ & Apple 4 & $\begin{array}{l}\text { Comp } \\
\text { Hetero }\end{array}$ & Asymptomatic & \\
\hline Father, 1963 & 51 & p.Phe301Leu & Exon 9 & Apple 4 & Hetero & Asymptomatic & \\
\hline Mother, 1962 & 84.8 & c. $595+3 A>G$ & Intron 6 & - & Hetero & Asymptomatic & \\
\hline \multicolumn{8}{|l|}{ Family 11} \\
\hline P11, F, 2005 & 5.5 & $\begin{array}{l}\text { p.Phe301Leu } \\
\text { p.Trp519 }\end{array}$ & $\begin{array}{l}\text { Exon } 9 \\
\text { Exon } 13\end{array}$ & $\begin{array}{l}\text { Apple } 4 \\
\text { Catalytic }\end{array}$ & $\begin{array}{l}\text { Comp } \\
\text { Hetero }\end{array}$ & Surgery-related bleeding & $\begin{array}{l}\text { Abdominal surgery for intestinal } \\
\text { atresia (transfusions required) }\end{array}$ \\
\hline Father, 1972 & 114 & p.Trp519a & Exon 13 & Catalytic & Hetero & Asymptomatic & \\
\hline Mother, 1981 & 84.8 & p.Phe301Leu & Exon 9 & Apple 4 & Hetero & Asymptomatic & \\
\hline Brother, 2010 & 47.4 & p.Trp519 & Exon 13 & Catalytic & Hetero & Asymptomatic & \\
\hline \multicolumn{8}{|l|}{ Family 12} \\
\hline P12, F, 1986 & 7 & $\begin{array}{l}\text { p.Glu315Lys } \\
\text { p.Trp519 }\end{array}$ & $\begin{array}{l}\text { Exon } 9 \\
\text { Exon } 13\end{array}$ & $\begin{array}{l}\text { Apple } 4 \\
\text { Catalytic }\end{array}$ & $\begin{array}{l}\text { Comp } \\
\text { Hetero }\end{array}$ & $\begin{array}{l}\text { Vaginal bleeding at the } \\
16 \text { th week of pregnancy }\end{array}$ & Pregnancy \\
\hline Father, 1963 & 35.8 & p.Trp519a & Exon 13 & Catalytic & Hetero & Asymptomatic & \\
\hline Mother, 1964 & 38.9 & p.Glu315Lys & Exon 9 & Apple 4 & Hetero & Asymptomatic & Appendicectomy \\
\hline Sister, 1988 & 28.9 & p.Glu315Lys & Exon 9 & Apple 4 & Hetero & Asymptomatic & \\
\hline \multicolumn{8}{|l|}{ Family 13} \\
\hline P13, F, 2005 & 37.2 & p.Arg326His & Exon 9 & Apple 4 & Hetero & Asymptomatic & \\
\hline Mother, 1969 & 59.7 & p.Arg326His & Exon 9 & Apple 4 & Hetero & Asymptomatic & \\
\hline \multicolumn{8}{|l|}{ Family 14} \\
\hline P14, F, 1964 & 45 & p.Gly418Val & Exon 11 & Catalytic & Hetero & $\begin{array}{l}\text { Easy bruising, }{ }^{a} \text { cerebellar } \\
\text { ischemia in oral contraceptive }\end{array}$ & $\begin{array}{l}\text { Appendicectomy; adeno-tonsillectomy; } \\
\text { abdominoplasty }\end{array}$ \\
\hline
\end{tabular}




\begin{tabular}{|c|c|c|c|c|c|c|c|}
\hline P15, F, 1992 & 36 & p.Trp151Gly & Exon 13 & Catalytic & Hetero & Asymptomatic & $\begin{array}{l}\text { Four pregnancies; appendicectomy; } \\
\text { hysterectomy; arthroscopic rotator } \\
\text { cuff repair }\end{array}$ \\
\hline \multicolumn{8}{|l|}{ Family 16} \\
\hline \multirow[t]{2}{*}{ P16, F, 2014} & 33.6 & p.Glu315Lys & Exon 9 & Apple 4 & Hetero & Asymptomatic & \\
\hline & & p.Ala561Asp & Exon 14 & Catalytic & Hetero & & \\
\hline \multirow[t]{2}{*}{ Mother, 1987} & 36.3 & p.Glu315Lys & Exon 9 & Apple 4 & Hetero & Asymptomatic & \\
\hline & & p.Ala561Asp & Exon 14 & Catalytic & Hetero & & \\
\hline
\end{tabular}

to collect as much information as possible. The diagnosis of the deficiency was performed on two consecutive blood withdrawals. Individuals with FXI activity levels $<15 \mathrm{IU} / \mathrm{dl}$ were defined as severely deficient, whereas those with levels of $20-50 \mathrm{IU} / \mathrm{dl}$ were defined as moderately deficient.

The present study was carried out according to the Principles of the Declaration of Helsinki - Ethical Principles for Medical Research Involving Human Subjects and approved through the local ethics committee.

\section{Coagulation tests}

Blood samples were collected in Na-citrated tubes. The samples were centrifuged at $2,500 \mathrm{~g}$ for $15 \mathrm{~min}$ to obtain plasma aliquots. The FXI activity levels were determined using a one-stage clotting assay (Siemens, Marburg, Germany), standardized using a homemade normal plasma pool. The reference interval, based on a locally performed reference range, was 70-150 IU/dl. The assay was performed using a BCS automated coagulation analyzer (Siemens AG). The detection limit of the FXI:C assay was $<1 \mathrm{IU} / \mathrm{dl}$. Reference intervals were obtained from the dosing plasma of 100 healthy blood donors from the local healthy population.

\section{DNA analysis}

DNA was extracted using standard procedures. The PCR reaction was performed in a total volume of $50 \mu \mathrm{l}$ containing $100 \mathrm{ng}$ of genomic DNA, $1 \mathrm{U}$ of HotStartTaq Plus DNA Polymerase (QIAGEN, Valencia, CA, USA), $1 \times$ PCR Buffer, $1 \times$ Q-Solution, $0.2 \mathrm{~mm}$ dNTPs, and $0.4 \mu \mathrm{m}$ of forward and reverse oligonucleotides. A typical PCR cycling protocol was optimized under the following conditions: an initial activation step of $5 \mathrm{~min}$ at $95^{\circ} \mathrm{C}$, followed by 35 cycles at $94^{\circ} \mathrm{C}$ for $1 \mathrm{~min}, 63^{\circ} \mathrm{C}$ for $55 \mathrm{~s}, 72^{\circ} \mathrm{C}$ for $1 \mathrm{~min}$, and a final extension of $10 \mathrm{~min}$ at $72{ }^{\circ} \mathrm{C}$. Direct sequencing of the coding regions, intron-exon boundaries, and $5^{\prime}$ and $3^{\prime}$ non-translated regions of the F11 (GenBank accession number NT_022792) was performed to detect mutations. The sequences were obtained using a BigDyeTerminator v3.1 Cycle Sequencing kit and the ABI PRISM 3130 Genetic Analyzer Sequencer (PE Biosystems, Foster City, CA, USA).

\section{In silico predictions}

Multiple alignment of F11 sequences was generated using the computer program MUSCLE (version 3.6) ${ }^{14}$ on the HomoloGene automated system (http://www.ncbi.nlm.nih.gov/homologene). Deleterious and damaging effect of missense mutations was predicted using the web-based tools SIFT (Sorting Intolerant from Tolerant, http://sift.bii.a-star.edu.sg/), and Polyphen-2 (Polymorphism Phenotyping v2, http://genetics.bwh.harvard. edu/pph2/). ${ }^{15,16}$ Residue change was classified as damaging with SIFT prediction scores ranging from 0.00 to 0.05 and with Polyphen-2 prediction according to the score ranging from (0 to 1 ), with 1 as the damaging prediction score. In SIFT, the median sequence information, measuring the diversity of the sequences used for prediction, is considered significant when lower than 3.25. The 'median info' is the median of conservation values in the alignment at the position of the substitution. If a substitution is predicted as damaging, with a median conservation value greater than 3.25 , then SIFT highlights the lack of diversity in the selected sequences. ${ }^{15}$

\section{RESULTS}

Clinical features and bleeding history

We studied 16 (12 females and 4 males) unrelated subjects with reduced FXI activity (Table 1). Clinical and laboratory information are reported in Table 1 . Five out of 16 individuals had severe deficiency $(<15 \mathrm{IU} / \mathrm{dl})$. The remaining 11 individuals showed levels between 33 and $46 \mathrm{IU} / \mathrm{dl}$. Two (P11 and P12) out of 5 individuals with severe deficiency displayed a bleeding tendency, which was observed after abdominal surgery (P11) and during pregnancy (P12), respectively.

\section{Sequence variants}

We identified 15 sequence variants (Table 1). All the mutations were previously described. In detail, 14 sequence variants were located in the F11 coding region, responsible for 11 missense and 2 nonsense mutations, and 2 sequence variants were located within a splice donor site. To our knowledge, the c.1682G $>$ A (p.Ala561Asp) allele variation is novel. Based on SIFT (score 0.00; median conservation value of 2.36) and Polyphen-2 (score 1.00) predictions, the change p.Ala561Asp could have a damaging effect on FXI structure. We identified the p.Ala561Asp combined in cis (analysis of trio family showed that the mother and the father were a heterozygous carrier and wild type for the p.Glu315Lys and p.Ala561Asp missense changes, respectively) with p.Glu315Lys mutation in a P16 individual who showed FXI levels of $33.6 \%$. In addition, multiple alignment of $\mathrm{FXI}$ amino acid sequences revealed that the p.Ala561 is a highly conserved residue across compared species (Figure 1). The 2 splice site variants were previously described to affect the normal splicing process of exons 4 and $6 .^{17,18}$ No mutations were observed in regions controlling gene expression ( $5^{\prime}$ non-translated flanking regions) or mRNA stability ( $3^{\prime}$ non-translated region). Overall, mutations dispersed over the entire gene with no evidence of clustering at specific coding and non-coding regions (Table 1 ) but primarily involved residues in the Ap2 or Ap4 domains (Figure 2). The c.325G >A (p.Ala108Thr) variant alters the physiological donor splice site, resulting in the skipping of exon $4 .{ }^{17}$ The most common F11 mutations identified in Ashkenazi Jews, i.e., p.Glu135* (type II; 26.5\%, 4/15) and p.Phe301Leu (type III; 13.3\%, 2/15), were detected in 6 probands.

\section{Clinical data and genetic findings}

With respect to the bleeding phenotype, 4 probands ( 2 with a severe and 2 a moderate deficiency) showed bleeding complications. All severe FXI patients $(n=5)$ were combined heterozygotes and in 4 of these individuals, to our knowledge, the combination was not previously described. The only 2 severely deficient 


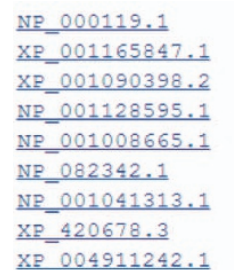

546
546
695
545
546
545
477
554
551

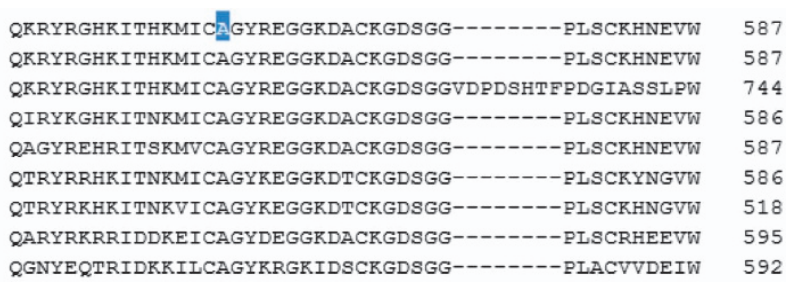

Figure 1. Multiple alignment of Factor XI (FXI) amino acid sequences. The Alanine-543 (numbering is reported without the signal peptide of 18 residues) is highlighted. Species compared are the following NP_000119.1 H.sapiens, XP_001165847.1 P.troglotydes, XP_001090398.2 Mmulatta, NP_001128595.1 C.lupis, NP_001008665.1 Btamms, NP_082342.1 Mmusculus, NP_001041313.1 R norvegicus, XP_420678.3 G.gallus, and XP_004911242.1 tropicalis.

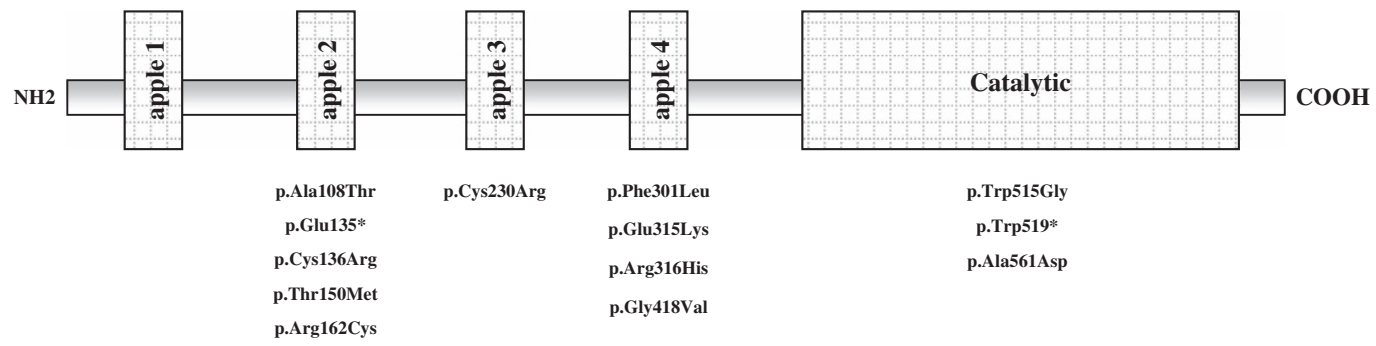

Figure 2. Distribution along the Factor XI (FXI) domains of the missense mutations identified.
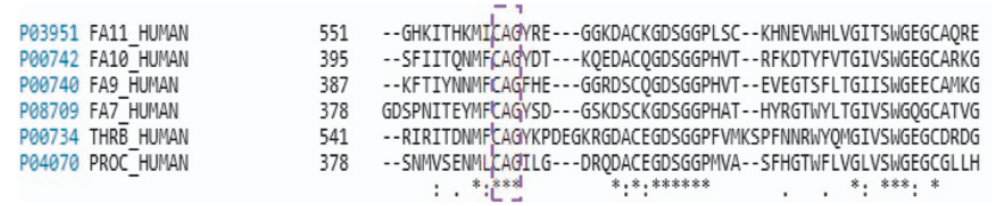

603
447
439
432
598
430

Figure 3. Multiple alignment of Factor XI (FXI) amino acid sequence with other serine proteases involved in the coagulation system, using Clustal Omega program. Highlighted within dashed box the well conserved Cysteine-Alanine-Glycine ('CAG') sequence. P03951 Uniprot ID Coagulation factor Xl; P00472 Uniprot ID Coagulation factor X; P00740 Uniprot ID Coagulation factor IX; P08709 Uniprot ID Coagulation factor VII; P00734 Uniprot ID Prothrombin; P04070 Uniprot ID Vitamin K-dependent protein C.

patients who bled, carried the p.Glu315Lys/p.Trp519* (P11) and p. Phe301Leu/p.Trp519* mutations (P12), respectively (Table 1).

\section{DISCUSSION}

Consistent with other reports, the cohort of probands and relatives described herein is highly heterogeneous in terms of clinical and genetic findings. Among individuals with moderate deficiency, 7 individuals underwent surgical procedures either at fibrinolytic (e.g., tonsillectomy and genitourinary disorders) or non-fibrinolytic sites (e.g., pilonidal sinus) without suffering from any bleeding manifestations. In addition, 1 (P15) individual had four uneventful pregnancies. Two thrombotic events (1 idiopathic superficial vein thrombosis and 1 cerebellar ischemia during oral contraceptives) were also recorded in 2 out of 10 (20\%) probands with moderate deficiency, suggesting that the occurrence of a thrombotic event is not a rare circumstance in subjects with this biochemical phenotype.

Women with FXI deficiency often experience significant obstetric and gynecological morbidity. ${ }^{19,20}$ Kadir et al. ${ }^{19}$ studied obstetric outcomes in women with FXI deficiency of Ashkenazi Jewish ancestry and observed a higher incidence of pregnancy complications in those with von Willebrand's disease than in those with FXI deficiency. In the women in the present study cohort (11 probands and 12 relatives), we recorded 10 pregnancies, 1 of which was complicated by a bleeding episode at the 16th week of gestation in a P12 patient. Notably, two pregnancies in 1 woman with severe deficiency (P5) were uneventful. The P12 patient was diagnosed at our center during her first pregnancy for unexplained vaginal bleeding that was successfully treated with tranexamic acid. Consistent with the data reported thus far, we detected the low prevalence of bleeding episodes during pregnancy and puerperium. Furthermore, tranexamic acid is confirmed to be efficacious in managing bleeding complications related to pregnancy.

In the present study, most of the identified genetic variants are missense mutations, consistent with the data reviewed by Duga et al. ${ }^{21}$

More than $50 \%(8 / 15)$ of the probands in the present case series carried mutations in the Ap2 domain, described as a key determinant of interactions between FXI and high-molecularweight kininogen, a molecule that facilitates the activation of $\mathrm{FXI}$ on platelets. ${ }^{22}$ Mutations in the Ap2 domain are not frequently identified in FXI-deficient patients (http://www.factorxi.org), although these mutations frequently occurred in an Italian series. $^{22}$

In the present cohort, type II mutation was significantly present, consistent with other studies ${ }^{8,22}$ reporting the high prevalence of this mutation in Italian patients. Interestingly, we observed the type III mutation in 2 patients. To date, only 2 Italian patients with the p.Phe301Leu have been described ${ }^{8,23}$ and both individuals were compound heterozygotes showing a bleeding tendency. In the present study, p.Phe301Leu was detected in combination with nonsense or splice site mutations. These mutations are responsible for a null allele, explaining the hemorrhagic phenotype. We propose that the p.Phe301Leu associated with a null allele could determine low FXI levels, thereby predicting a bleeding phenotype. 
The p.Glu315Lys mutation was previously characterized and implicated in lowering the secretion rate of FXI to $4.5 \%$ of that of the wild type. ${ }^{24}$ This mutation has primarily been identified in French patients as well as in an Israeli Arab heterozygous 15-yearold female showing menorrhagia and epistaxis. ${ }^{24,25}$ Bleeding was also observed in a Belgian woman who showed compound heterozygosity involving p.Glu315Lys and p.Cys545Tyr, and bleeding episodes after tooth extractions. The proband P12, showing p.Glu315Lys in association with a nonsense mutation in the catalytic site (p.Trp519*), suffered from vaginal bleeding during pregnancy (at the 16th week), whereas her mother, carrying only p.Glu315Lys, did not bleed during surgery. We propose that in this family, the presence of a nonsense mutation combined with the p.Glu315Lys is a determinant for the occurrence of bleeding complication. Notably, bleeding tendency was also recorded in proband P11, who displayed the p.Trp519* mutation together with another variant in the Ap4 domain, p.Phe301Leu. However, the presence of the homozygosity for the p.Trp519*, described in a Japanese patient who underwent gastrectomy, was not associated with bleeding episodes. ${ }^{26}$ The Ap4 domain has a crucial role in FXI zymogen activation, ensuring the proper folding and dimerization of FXI. $^{27}$ The p.Glu315Lys variation combines in cis with the novel mutation p.Ala561Asp. In the present and previous studies, p.Glu315Lys heterozygous subjects showed FXI levels similar to those observed in the P16 subject: the novel mutation p.Ala561Asp in cis does not apparently influence the FXI levels or clinical phenotype. However, prediction models suggest a deleterious effect, and Ala-561 is in the middle of the Cysteine-Alanine-Glycine sequence. The 'Cysteine-Alanine-Glycine' sequence is highly conserved among serine proteases (Figure 3), suggesting a main functional and structural role for these residues in this class of proteins. Missense changes involving the Cysteine-Alanine-Glycine residues either of the other serine proteases of the coagulation system or of F11 have been described. ${ }^{28-38}$ Therefore, we speculated that $p$. Ala561Asp, when present in homozygosity or in trans, could influence plasmatic levels and/or bleeding tendency. In the present study, bleeding episodes were not recorded in the proband P10, who showed p.Phe301Leu combined with the c.595 $+3 A>G$, whereas bleeding complications were reported when this missense mutation is combined with p.Trp519* (P11 and P12), as previously described. With respect to the c.595+3 A>G mutation, alterations in the splicing process have previously been demonstrated ${ }^{17}$ and described in an asymptomatic Italian subject showing compound heterozygosity; in the homozygous state, alterations in the splicing process were described in an Italian patient who showed a bleeding episode after knee arthroscopy. ${ }^{22}$ To our knowledge, the only heterozygosis for c.595+3 A>G was described in two Caucasian patients who never bled. ${ }^{39,40}$

The p.Gly418Val variant has been previously identified in FXI-deficient patients who showed dental or gingival bleeding; one of these patients was of Italian origin. ${ }^{40}$ We detected this variant in a moderately deficient woman with easy bruising (P14), but with no bleeding episodes during surgery; notably, she suffered from cerebellar ischemia when she was taking birth control pills, suggesting that the bleeding tendency may not enough to avoid thrombotic events, at least in the presence of triggers. The data in the present study confirm the wide heterogeneity of the clinical and biochemical findings in subjects showing the FXI deficiency. A novel potentially deleterious mutation in the catalytic domain was reported. Additional studies are needed to better define the genotype-phenotype relationship in FXI-deficient subjects.

\section{ACKNOWLEDGEMENTS}

We thank the patients involved in the present study. The work was financially supported by a grant from the Ministry of Health, Italy.

\section{COMPETING INTERESTS}

The authors declare no conflict of interest.

\section{REFERENCES}

1 Salomon O, Seligsohn U. New observations on factor XI deficiency. Haemophilia 2004; 10: 184-187.

2 Bolton-Maggs PH, Pasi KJ. Haemophilias A and B. Lancet 2003; 361: 1801-1809.

3 Gomez K, Bolton-Maggs P. Factor XI deficiency. Haemophilia 2008; 14: 1183-1189.

4 Mulder R, Wiewel-Verschueren S, Meijer K, Mulder AB. Identification of a novel factor XI gene mutational event in a Dutch Caucasian family with inherited factor XI deficiency. Thromb Haemost 2013; 109: 1183-1185.

5 Seligsohn U. Factor XI deficiency in humans. J Thromb Haemost 2009; 7: 84-87.

6 Seligsohn U. High gene frequency of factor XI (PTA) deficiency in Ashkenazi Jews. Blood 1978; 51: 1223-1228.

7 Peretz H, Mulai A, Usher S, Zivelin A, Segal A, Weisman Z et al. The two common mutations causing factor $\mathrm{XI}$ deficiency in Jews stem from distinct founders: one of ancient Middle Eastern origin and another of more recent European origin. Blood 1997; 90: 2654-2659.

8 Zadra G, Asselta R, Tenchini ML, Castaman G, Seligsohn U, Mannucci PM et al. Simultaneous genotyping of coagulation factor XI type II and type III mutations by multiplex real-time polymerase chain reaction to determine their prevalence in healthy and factor XI-deficient Italians. Haematologica 2008; 93: 715-721.

9 Asakai R, Chung DW, Davie EW, Seligsohn U. Factor XI deficiency in Ashkenazi Jews in Israel. N Engl J Med 1991; 325: 153-158.

10 Salomon O, Steinberg DM, Seligsohn U. Variable bleeding manifestations characterize different types of surgery in patients with severe factor XI deficiency enabling parsimonious use of replacement therapy. Haemophilia 2006; 12: 490-493.

11 Bolton-Maggs PH, Patterson DA, Wensley RT, Tuddenham EG. Definition of the bleeding tendency in factor $\mathrm{XI}$-deficient kindreds--a clinical and laboratory study. Thromb Haemost 1995; 73: 194-202.

12 Salomon O, Steinberg DM, Tamarin I, Zivelin A, Seligsohn U. Plasma replacement therapy during labor is not mandatory for women with severe factor XI deficiency. Blood Coagul Fibrinolysis 2005; 16: 37-41.

13 Rapaport SI, Proctor RR, Patch MJ, Yettra M. The mode of inheritance of PTA deficiency: evidence for the existence of major PTA deficiency and minor PTA deficiency. Blood 1961; 18: 149-165.

14 Edgar RC. MUSCLE: multiple sequence alignment with high accuracy and high throughput. Nucleic Acids Res 2004; 32: 1792-1797.

15 Kumar P, Henikoff S, Ng PC. Predicting the effects of coding non-synonymous variants on protein function using the SIFT algorithm. Nat Protoc 2009; 4: 1073-1108.

16 Adzhubei I, Jordan DM, Sunyaev SR. Predicting functional effect of human missense mutations using PolyPhen-2. Curr Protoc Hum Genet 2013; Chapter 7: Unit 7.20 .

17 Guella I, Soldà G, Spena S, Asselta R, Ghiotto R, Tenchini ML et al. Molecular characterization of two novel mutations causing factor XI deficiency: a splicing defect and a missense mutation responsible for a CRM+defect. Thromb Haemost 2008; 99: 523-530.

18 Mitchell M, Mountford R, Butler R, Alhaq A, Dai L, Savidge G, Bolton-Maggs PH. Spectrum of factor XI (F11) mutations in the UK population--116 index cases and 140 mutations. Hum Mutat 2006; 27: 829.

19 Kadir RA, Lee CA, Sabin CA, Pollard D, Economides DL. Pregnancy in women with von Willebrand's disease or factor XI deficiency. Br J Obstet Gynaecol 1998; 105 : 314-321.

20 Bolton-Maggs PH. Bleeding problems in factor XI deficient women. Haemophilia 1999; 5: 155-159.

21 Duga S, Salomon O. Congenital factor XI deficiency: an update. Semin Thromb Hemost 2013; 39: 621-631.

22 Castaman G, Giacomelli SH, Caccia S, Riccardi F, Rossetti G, Dragani A et al. The spectrum of factor XI deficiency in Italy. Haemophilia 2014; 20: 106-113.

23 Castaman G, Giacomelli SH, Dragani A, Iuliani O, Duga S, Rodeghiero F. Severe factor XI deficiency in the Abruzzo region of Italy is associated to different FXI gene mutations. Haematologica 2008; 93: 957-958.

24 Zucker M, Zivelin A, Landau M, Salomon O, Kenet G, Bauduer F et al. Characterization of seven novel mutations causing factor XI deficiency. Haematologica 2007; 92: 1375-1380.

25 Quélin F, Mathonnet F, Potentini-Esnault C, Trigui N, Peynet J, Bastenaire B et al. Identification of five novel mutations in the factor XI gene (F11) of patients with factor XI deficiency. Blood Coagul Fibrinolysis 2006; 17: 69-73.

26 lijima K, Udagawa A, Kawasaki H, Murakami F, Shimomura T, Ikawa S. A factor XI deficiency associated with a nonsense mutation (P.Trp519*) in the catalytic domain. Br J Haematol 2000; 111: 556-558. 
27 Samuel D, Cheng H, Riley PW, Canutescu AA, Nagaswami C, Weisel JW et al. Solution structure of the A4 domain of factor XI sheds light on the mechanism of zymogen activation. Proc Natl Acad Sci USA 2007; 104: 15693-15698.

28 O'Connell NM, Saunders RE, Lee CA, Perry DJ, Perkins SJ. Structural interpretation of 42 mutations causing factor XI deficiency using homology modeling. J Thromb Haemost 2005; 3: 127-138.

29 Chan V, Chan VW, Yip B, Chim CS, Chan TK. Hemophilia B in a female carrier due to skewed inactivation of the normal X-chromosome. Am J Hematol 1998; 58: 72-76.

30 Kwon MJ, Yoo KY, Kim HJ, Kim SH. Identification of mutations in the F9 gene including exon deletion by multiplex ligation-dependent probe amplification in 33 unrelated Korean patients with haemophilia B. Haemophilia 2008; 14: 1069-1075.

31 Wu Y, Wang Y, Lan F, Zhu Z, Fang G, Yang W. A novel missense mutation (C329Q) in factor VII gene. Blood 2000; 95: 3638-3640.

32 Millar DS, Kemball-Cook G, McVey JH, Tuddenham EG, Mumford AD, Attock GB et al. Molecular analysis of the genotype-phenotype relationship in factor VII deficiency. Hum Genet 2000; 107: 327-342.

33 Herrmann FH, Wulff K, Auerswald G, Schulman S, Astermark J, Batorova A et al. Greifswald Factor FVII Deficiency Study Group. Factor VII deficiency: clinical manifestation of 717 subjects from Europe and Latin America with mutations in the factor 7 gene. Haemophilia 2009; 15: 267-280.

34 Millar DS, Elliston L, Deex P, Krawczak M, Wacey Al, Reynaud J et al. Molecular analysis of the genotype-phenotype relationship in factor $\mathrm{X}$ deficiency. Hum Genet 2000; 106: 249-257.

35 Miyata T, Kojima T, Suzuki K, Umeyama H, Yamazaki T, Kamiya T et al. Factor X Nagoya 1 and Nagoya 2: a CRM- factor $X$ deficiency and a dysfunctional CRM+ factor X deficiency characterized by substitution of Arg306 by Cys and of Gly366 by Ser, respectively. Thromb Haemost 1998; 79: 486-490.
36 Saunders RE, Shiltagh N, Gomez K, Mellars G, Cooper C, Perry DJ et al. Structural analysis of eight novel and 112 previously reported missense mutations in the interactive FXI mutation database reveals new insight on FXI deficiency. Thromb Haemost 2009; 102: 287-301.

37 Poort SR, Pabinger-Fasching I, Mannhalter C, Reitsma PH, Bertina RM. Twelve novel and two recurrent mutations in 14 Austrian families with hereditary protein C deficiency. Blood Coagul Fibrinolysis 1993; 4: 273-280.

38 Alhenc-Gelas M, Gandrille S, Aubry ML, Aiach M. Thirty-three novel mutations in the protein $C$ gene. French INSERM network on molecular abnormalities responsible for protein $C$ and protein S. Thromb Haemost 2000; 83: 86-92.

39 Zivelin A, Bauduer F, Ducout L, Peretz H, Rosenberg N, Yatuv R et al. Factor XI deficiency in French Basques is caused predominantly by an ancestral Cys38Arg mutation in the factor XI gene. Blood 2002; 99: 2448-2454.

40 Kravtsov DV, Wu W, Meijers JC, Sun MF, Blinder MA, Dang TP et al. Dominant factor XI deficiency caused by mutations in the factor XI catalytic domain. Blood 2004; 104: 128-134.

(c) (i) $(-)$ This work is licensed under a Creative Commons AttributionNonCommercial-NoDerivs 4.0 International License. The images or other third party material in this article are included in the article's Creative Commons license, unless indicated otherwise in the credit line; if the material is not included under the Creative Commons license, users will need to obtain permission from the license holder to reproduce the material. To view a copy of this license, visit http:// creativecommons.org/licenses/by-nc-nd/4.0/

(c) The Author(s) 2017 